\title{
Methodologies of Change in the Contemporary Islamic World
}

\author{
12-14 Sha'bān 1414/24-26 January 1994 \\ Kuwait City, Kuwait
}

This seminat was the second in a series of seminars held jointly by the Intemational Institute of Islamic Thought (IIIT) in cooperation with the Kuwaiti Department of Awqaf. The inaugural session of the seminar was addressed by the Minister for Awqaf and Islamic Affairs, Jam'ān al 'Ázimi, who stated that the topic of the seminar sufficed to indicate its importance. The following speaker, the Secretary of the Ministry, Khālid al Zir, underlined the fact that while everyone agreed on the need to retum to the pristine teachings of the Qur'an and the Sunnah, it was not an easy matter to determine how, in practical terms, this might be achieved. This is why, the Secretary said, this seminar was convened.

Tāhā Jābir al 'Alwāñ, President of the Intemational Institute of Islamic Thought, after making his opening remarks, delivered a paper entitled The Horizons of Change and Its Approaches, in which he stated that the Arab world had very recently reached a critical stage. Many analytical studies of various aspects of the Arab situation, he added, had been conducted from several different perspectives. Undoubtedly, on the basis of these studies, the outlines of an alternative civilizational project may emerge. It is for this reason that the topic of the seminar, "Methodologies of Change in the Contemporary Islamic World," is of such overwhelming importance.

Muhammad al Ghazāli, the noted Muslim 'âlim and author, then spoke on behalf of the seminar participants. Prefacing his remarks by noting the importance of Kuwait in the Arab and Muslim worlds, al Ghazāi explained that it is the duty of Muslims everywhere to work together to further the cause of Islam. This is why, he added, the cooperation of the Kuwaiti Ministry with the International Institute of Islamic Thought was such a commendable undertaking.

The seminar was comprised of four distinctive themes. The first one dealt with defining the concept of change within the Islamic paradigm, beginning with the Qur'an, the Sunnah, and the historical experience of Islam. This concept may be studied in light of the theories and opinions of the classical scholars of Islam. In addition, it may prove beneficial to study it in conjunction with such similar concepts within the Islamic paradigm as tajdid, reform, revival, awakening, revolution, modemization, development, and progress. Topics for discussion included the following: 
the Qur'anic methodology of change (including not only interpretation but new ijtihad for the application of Qur'anic precepts in the contemporary world); the methodology of change in the Sunnah (with particular reference to the maqāssid); change in Islamic history; and a survey of views and opinions held by the classical scholars of Islam on the subject of change.

The second theme was a survey of conditions in contemporary Islamic societies. This included analyses of the cultural and intellectual atmosphere as indicators of these societies' mentality. Studies focussed on culture and its shortcomings and whether these were the result of extinct ideas from our past or of perilous ideas imported from other cultures. The following topics were discussed: ethics and values in Muslim society; economic and valuational aspects of Muslim culture; the sociology of culture in Islamic society today; the culture of politics in Islamic society today; and the religious aspect of Islamic society today.

The third theme dealt with the methodologies of change favored by contemporary Islamic movements: descriptive, analytical, and critical studies that identified the positive and the negative aspects of these methodologies and specified where and how each either failed or succeeded. Topics discussed were: individual spiritual methodologies of change; educational and indoctrinational methodologies; and violent methodologies of change.

The final theme analyzed plurality in the organization and structure of contemporary Islamic movements. What has been the nature of relations between these movements and other elements of society as well as between the different movements themselves? What have been the effects of organizational plurality on the success or failure of these movements? Also discussed were: the legitimacy of organizations independent of the ummah; the Islamic view of diversity in reform; organizational plurality; and the lack of methodology and well-defined principles.

Those presenting papers at the seminar included: "Abd al Jalil al Gharaballi, Values Determining Economic Behavior in the Arab Gulf; 'Alī Jumu'ah, The Philosophy of Change; Fahmī Jad'ān, Islam and Change by Coercion; Tāriq al Bishrī, The Historical Framework of Islamic Revival Movements; Ahmad Șidqī al Dajjānī; Muhammad Abū al Qāsim; Muhammad 'Ammārah, Secularist Criticisms of the Islamic Plan for Revival; Ja'far Shaykh Idrīs; Muhammad al Rumayhī, Values and Morals that Influence Culture in the Gulf; Mubammad al Sammāk, The Role of Media in Influencing Culture and Belief in the Arab World; Abmad Buzabar, Modern Theories of Change and Islamic Thought; Wajīh Kawtharānī, Why Think of Malik Bennabi when Change is Mentioned: Remembering, Forgetting, and Continuing in Arab Islamic 
Thought; Sādiq al 'Ibādī, Change Methodology in Shi'i Thought; 'Abd al Latîf, 'Ibädah, Change Methodologies of Contemporary Islamic Movements: Critical Analysis from the Ideas of Malik Bennabi; and Qays Khaz'al, Attempts at Change by Means of Military Takeover.

Yusuf Talal DeLorenzo IIIT Research Department Herndon, Virginia 